\title{
RELATIONSHIP BETWEEN FAMILY SUPPORT AND MEDICAL COMPLIANCE IN PATIENTS WITH PULMONARY TUBERCULOSIS IN THE WORKING AREA OF THE COMMUNITY HEALTH CENTER OF ABELI, KENDARI
}

\author{
Ruth Mongan*, Fajar \\ Polytechnic of Health Kendari, Ministry of Health Republic of Indonesia
}

Accepted: 8 March 2017

*Correspondence:

Ruth Mongan, BSc., S.Pd., M.Pd.

Polytechnic of Health Kendari, Ministry of Health Republic of Indonesia.

E-mail: ruth.mongan0401@gmail.com

Copyright: (C) the author(s), YCAB publisher and Public Health of Indonesia. This is an open-access article distributed under the terms of the Creative Commons Attribution Non-Commercial License, which permits unrestricted non-commercial use, distribution, and reproduction in any medium, provided the original work is properly cited.

\begin{abstract}
Background: Little is known about the relationship between family support (emotional, material, and informational support) with medical compliance in tuberculosis patients in the Community Health Center of Abeli Kendari

Objective: This study aims to examine the relationships of family support (emotional, material, and informational support) and medical compliance of patients with pulmonary tuberculosis.

Methods: This was an observational study with cross-sectional design. Thirty samples were recruited by total sampling with the criteria that they had pulmonary TB with positive acid-resistant bacteria and still taking medication from the community health center of Abeli Kendari health center. Data were analyzed by chi-square processed using univariate and bivariate and presented in tabular form and narrated.

Results: Findings showed that there were significant relationship between Emotional support $\left(\mathrm{X}_{\text {hit }}^{2}=10.20\right.$ $>$ the value of $\mathrm{X}_{\text {tab }}^{2}=3.841 ; \mathrm{Cc} 0.50$ - moderate relationship $)$, material support $\left(\mathrm{X}_{\text {hit }}^{2}=6.00>\right.$ the value of $\mathrm{X}_{\text {tab }}^{2}=3.841 ; \mathrm{Cc} 0.41$ - moderate relationship), and informational support $\left(\mathrm{X}_{\text {hit }}^{2}=13.50>\right.$ the value of $\mathrm{X}_{\text {tab }}^{2}$ $=3.841 ; \mathrm{Cc} 0.56-$ strong relationship) with $\mathrm{p}$-value $<0.05$.

Conclusion: there was a significant relationship between family support (emotional, material, and informational support) with medical compliance of patients with pulmonary tuberculosis. It is suggested for health professionals to always promote the importance of family support for the successful of medical treatment among tuberculosis patients.
\end{abstract}

Key words: family support, medical compliance, pulmonary tuberculosis

\section{INTRODUCTION}

Pulmonary tuberculosis (TB) is still a worldwide health problem, especially in developing countries such as Indonesia and the re-emergence in industrialized countries. Indonesia is a country of high- burden countries along with 21 other countries. The prevalence of all tuberculosis cases occurring in Indonesia is estimated at 660,000 and approximately 430,000 new cases each year. The victim died from TB in Indonesia is estimated as 
many as 61,000 deaths each year. ${ }^{1}$ According to the World Health Organization (WHO) in 2012, Indonesia was in fourth position with the number of cases about 0.4 million to 0.5 million under India, China, and South Africa. ${ }^{2}$ One indicator of TB controls is the Case Detection Rate (CDR), namely the discovery of new cases of TB with positive acid-resistant bacteria at least $70 \%$ of the estimation; and Success Rate (SR) of treatment is at least $85 \%$ of all the patients and keep it. ${ }^{3}$

Report of the results of the survey in 2004 showed that the prevalence of pulmonary tuberculosis by microscopic of acid-resistant bactery positive was 110 per 100,000 population. While the results of the Basic Health Research (Riskesdas) in 2010 showed that the prevalence of tuberculosis based on the recognition of respondents diagnosed by health professionals nationally was 0.7 percent. It means there is an increase in the prevalence rate compared to Riskesdas in 2007, namely $(0.4 \%)^{4}$

Since 1995, pulmonary tuberculosis eradication program has been implemented with the strategy of Directly Observed Treatment Shortcourse Chemotherapy (DOTS) recommended by the WHO, which is the most appropriate approach at this time and must be truly implemented. The program emphasizes on correct and proper diagnosis followed by effective short-term treatment and monitoring. The treatment success rate reached $85 \%$. The short-term goal of the prevention of Pulmonary Tuberculosis is to reduce morbidity and mortality rate of lung TBC by breaking the chain of transmission, so that the lung $\mathrm{TBC}$ is no longer a public health problem in Indonesia. ${ }^{4}$

The incidence of lung TB In Southeast Sulawesi in 2010 with suspected pulmonary was 9,196 cases, and positive acid-resistant bacteria was 4,302 cases. In
2011 the number of pulmonary TB patients has risen to be 10,813 suspected cases with 5,281 positive acid-resistant bacteria cases. While in 2012 suspected pulmonary TB was 12,115 and positive acid-resistant bacteria $6.734 .^{5}$ In this study, the incidence of pulmonary TB disease in Kendari in 2011 was 5,517 suspected cases and positive acid-resistant bacteria was 448 and got treatment with DOTS program. This incidence increased in 2012 with 6569 cases and 480 positive acid-resistant bacteria. The increased number of cases also occurred in the community health center of Abeli Kendali, which was 209 cases in 2011 to 228 cases in 2012. However, this cases decreased in 2013 with 97 cases, but this number is considered high. ${ }^{6}$

The success of the tuberculosis program is not just dependent on the health professional, but also from the family support. Family support means the existence of comfort, attention, appreciation or to help people with an attitude of accepting the conditions, obtained from individuals and group. ${ }^{7}$ Friedman (1998) divides the four dimensions of family support, namely Emotional Support, Appraisal Assistance, material, and information support. ${ }^{8}$ Compliance to treatment requires the active participation of patients in self-care management and cooperation between the patient and health professionals. ${ }^{9}$ However, little is known about the relationships between family support with medical compliance in Kendari, therefore, the study aims to determine the relationship of family support with medical compliance in patients with pulmonary tuberculosis in the community health center of Abeli, Kendari.

\section{METHODS}

This study was an observational study with cross-sectional design, which all the 
variables studied at the same time and in the cross test between variables based on objective criteria. ${ }^{10}$ Thirty samples were recruited using total sampling in the working area of the community health center of Abeli Kendari. All the samples were all patients with pulmonary TB with positive acid-resistant bacteria that were still having medication from the community health center. All of them were diagnozed by medical doctor in that health center. Data were collected on May - June 2013 using direct observation and selfadministered questionnaire with accepted validity and reliability. The secondary data were also obtained from patients' medical record for the characteristic of respondents and kind of the treatments. Data were collected after obtaining permission from the community health center of Abeli Kendari. Informed consent was conducted to explain the purpose of the study and to maintain the confidentiality of the data. Respondents were asked to sign the informed consent form. Data were analyzed by chi-square processed using univariate and bivariate and presented in tabular form and narrated.

\section{RESULTS}

\section{Characteristic of respondents}

The characteristics of the respondents were explained in the Table 1, which showed that those who were suffering from tuberculosis were in both gender, male and female with almost the same average. The age of the respondents were majority in the age $38->67$, with Junior high school $(33.3 \%)$ and Senior high school $(63 \%)$ as their major educational background and only $1 \%$ of respondents graduated from university. Majority of respondents worked in private sectors $(36.7 \%)$, housewives $(26.7 \%)$, and farmers $(20 \%)$
Tabel 1. Characteristics of respondents in $2013(n=30)$

\begin{tabular}{|l|l|l|}
\hline Description & F & $\%$ \\
\hline Gender & 16 & 53.3 \\
\hline Male & 14 & 46.7 \\
\hline Female & \multicolumn{2}{l|}{} \\
\hline Age & 2 & 6.7 \\
\hline $18-27$ & 3 & 10.0 \\
\hline $28-37$ & 6 & 20.0 \\
\hline $38-47$ & 6 & 20.0 \\
\hline $48-57$ & 7 & 23.3 \\
\hline $58-67$ & 6 & 20.0 \\
\hline$>67$ & \multicolumn{2}{|l|}{} \\
\hline Education & 10 & 33.3 \\
\hline Junior High School & 19 & 63.4 \\
\hline Senior High School & 1 & 3.3 \\
\hline University & \multicolumn{2}{|l}{} \\
\hline Job & 1 & 3.3 \\
\hline Student & 11 & 36.7 \\
\hline Private & 6 & 20 \\
\hline Farmer & 3 & 10 \\
\hline Fisherman & 8 & 26.7 \\
\hline Housewives & 1 & 3.3 \\
\hline Government employee & \multicolumn{2}{|l}{} \\
\hline
\end{tabular}

\section{Relationship of Family Support and medical compliance in patients with tuberculosis}

Tabel 2 showed the three hree dimensions of family support and medical compliance in patients with tuberculosis in the working area of the community health center of Abeli Kendari in 2013. It is showed that for emotional support, those who got the emotional support and complying in TB medication were 22 respondents $(73.33 \%)$, and 2 respondents $(6.67 \%)$ did not comply; while those who did not get the emotional support had only 2 respondents were complying, 4 respondents were not. The results of statistical tests of chi-square values obtained $X^{2}{ }_{\text {hit }}=10.20$ and the value of $\mathrm{X}_{\text {tab }}^{2}=3.841$. It demonstrates that the value of $X^{2}{ }_{\text {hit }}>X_{\text {tab }}^{2}$ value with $p$-value $<$ 
0.05 showed that $\mathrm{H}_{\mathrm{o}}$ rejected and $\mathrm{H}_{\mathrm{a}}$ accepted. It means there is a relationship between emotional support and medical compliance. In addition, the statistic showed the value of $\mathrm{Cc}$ was 0.50 , which means a moderate relationship.

Table 2. Relationship of family support and medical compliance in patients with tuberculosis

\begin{tabular}{|c|c|c|c|c|c|c|c|}
\hline \multirow{3}{*}{ Family Support } & \multicolumn{4}{|c|}{ Medical compliance } & \multirow{3}{*}{$\mathbf{F}$} & \multirow{3}{*}{$\%$} & \multirow{3}{*}{ Chi-Square } \\
\hline & \multicolumn{2}{|c|}{ Complying } & \multicolumn{2}{|c|}{ Not Complying } & & & \\
\hline & $\mathbf{F}$ & $\%$ & $\mathbf{F}$ & $\%$ & & & \\
\hline \multicolumn{8}{|c|}{ Emotional Support } \\
\hline Support & 22 & 73.33 & 2 & 6,67 & 24 & 80.00 & $\mathrm{X}^{2}=10.20$ \\
\hline No support & 2 & 6,67 & 4 & 13,33 & 6 & 20.00 & $\mathrm{X}_{\mathrm{tab}}^{2}=3.841$ \\
\hline Total & 24 & 80.00 & 6 & 20.00 & 30 & 100.00 & $\mathrm{Cc}=0.50$ \\
\hline \multicolumn{8}{|l|}{ Material Support } \\
\hline Support & 22 & 73.33 & 3 & 10 & 25 & 83,33 & $X^{2}=6.00$ \\
\hline No support & 2 & 6.67 & 3 & 10 & 5 & 16.67 & $\mathrm{X}_{\mathrm{tab}}^{2}=3.841$ \\
\hline Total & 24 & 80 & 6 & 20 & 30 & 100 & $\mathrm{Cc}=0,41$ \\
\hline \multicolumn{8}{|c|}{ Information Support } \\
\hline Support & 23 & 76.67 & 2 & 6.67 & 25 & 83.33 & $X^{2}=13.50$ \\
\hline No Support & 1 & 3.33 & 4 & 13.33 & 5 & 16.67 & $\mathrm{X}_{\mathrm{tab}}^{2}=3.841$ \\
\hline Total & 24 & 80 & 6 & 20 & 30 & 100 & $\mathrm{~V}^{2}=0.56$ \\
\hline
\end{tabular}

For material support, Table 2 showed that those who got the material support and complying in TB medication were 22 respondents $(73.33 \%)$, and 3 respondents $(10.00 \%)$ did not comply; while those who did not get the material support had only 2 respondents were complying, 3 respondents were not. The results of statistical tests of chi-square values obtained $\mathrm{X}_{\text {hit }}^{2}=6.00$ and the value of $\mathrm{X}^{2}$ tab $=3.841$. It demonstrates that the value of $\mathrm{X}^{2}{ }_{\text {hit }}>\mathrm{X}_{\text {tab }}{ }_{\text {tab }}$ value with $\mathrm{p}$-value $<0.05$ showed that $\mathrm{H}_{\mathrm{o}}$ rejected and $\mathrm{H}_{\mathrm{a}}$ accepted. It means there is a relationship between material support and medical compliance. In addition, the statistic showed the value of $\mathrm{Cc}$ was 0.41 , which means a moderate relationship.

For informational support, table showed that those who got the informational support and complying in
TB medication were 23 respondents (76.67\%), and 2 respondents $(6.67 \%) \mathrm{did}$ not comply; while those who did not get the informational support had only 1 respondents were complying, 4 respondents were not. The results of statistical tests of chi-square values obtained $\mathrm{X}_{\text {hit }}=13.50$ and the value of $\mathrm{X}_{\text {tab }}^{2}=3.841$. It demonstrates that the value of $\mathrm{X}_{\text {hit }}^{2}>\mathrm{X}_{\text {tab }}^{2}$ value with $\mathrm{p}$-value $<0.05$ showed that $\mathrm{H}_{\mathrm{o}}$ rejected and $\mathrm{H}_{\mathrm{a}}$ accepted. It means there is a relationship between informational support and medical compliance. In addition, the statistic showed the value of $\mathrm{Cc}$ was 0.56 , which means a strong relationship.

\section{DISCUSSION}

Family support is a part of everyone's life and can not be separated. Patients will feel happy and at ease when getting the 
attention and support of her/his family, because with such support would cause her/his confidence to deal with or manage the disease well, and then they want to follow the advice given by the family to the management of the disease. This study is in line with research Goddess who said that there is significant correlation between family support with pulmonary TB medication adherence. ${ }^{11}$ Similarly with Zanani indicated that there was a relationship between family support compliance with pulmonary tuberculosis in anti-tuberculosis treatment in health centers of Torjun Sampang. ${ }^{7}$ Better family support will have better medical compliance. However, in this study, the family support was divided to be emotional support, material, and informational support. Thus, the findings were discussed in these three deimensions.

Findings of this study showed that there was a moderate relationship between emotional support and medical compliance of patients with pulmonary tuberculosis. This relationship occured because patients might feel comfortable, loved, and respected, like Erawatyningsih said that this type of support is referred to the encouragement, warmth, love, affection, and emotion. ${ }^{12}$ Emotional support is a behavior which gives a comfortable feeling and makes people believe that he/she is admired, respected and loved, and that someone else is willing to pay attention and give sense of security. Emotional support gives people a feeling of comfort, feel loved when you're depressed, aid in the form of encouragement, empathy, trust, attention, so that individuals who receive it feel valued. ${ }^{13}$ In addition, the moderate relationship of this emotional support in this study is in line with the theory, which indicates that because the assigned treatment needs long period of time, then there are several possible patterns of patient compliance that is classified into: gong for treatment regularly and taking medication regularly; and not going for treatment regularly and not taking medications regularly or stop taking medication. ${ }^{14}$

The finding of this study also revealed that there was a moderate relationship between material support and medical compliance. However, there was a difference material support in this study based on the criteria of the respondents, especially for their jobs, which might affect the relationship, like the theory said that material supports vary, such as in the form of money, equipment, time, environment modification, and helping in job. ${ }^{8}$ However, the material support is the concrite and real help for medical compliance of patients with tuberculosis.

On the other hand, informational support in this study had a strong realtionship with medical compliance of patients with tuberculosis. However, the informational support received by respondents might be different because of the difference level of educational background. But this finding revealed that informational support remains important for the medical compliance. Informational support from family is like the mediator of information in the world, including guidelines, advices, feedback, etc. It might include the information regarding medication and the patterns of diet. Thus, good informational support might reflect to the good compliance.

\section{CONCLUSION}

It could be concluded that there was a significant relationship between family support (emotional, material, and informational support) with medical compliance of patients with pulmonary tuberculosis. Therefore, it is suggested for health professionals to always promote the importance of family support for the successful of medical treatment among 
tuberculosis patients. However, the further studies also needed with bigger sample size to examine these factors on medical compliance.

\section{REFERENCES}

1. Indonesia KKR. Pedoman nasional pengendalian tuberkulosis.

Kemenkes RI. Jakarta. 2011.

2. Organization WH, Initiative ST. Treatment of tuberculosis: guidelines: World Health Organization; 2010.

3. MOH. National strategy for controlling TB in Indonesia 20102014, Ministry of Health Republic of Indonesia. 2011.

4. MOH. Basic of Health Research. 2010.

5. sulawesi HoSe. Health Profile South east sulawesi province. 2012.

6. district Hok. Profile of health kendari district. 2012.

7. Zanani M. Relationships with the Family Support Patient Medication Adherence pulmonary $T B$ in Puskesmas Torjun Sampang, Universitas Airlangga; 2009.

8. Friedman MM. Family nursing: Theory and assessment: AppletonCentury-Crofts; 1986.

9. Watkins RE, Plant AJ. Pathways to treatment for tuberculosis in Bali: patient perspectives. Qualitative Health Research. 2004;14(5):691703.

10. Notoatmodjo S. Methodology of health. Penerbit Rineka Cipta, Jakarta. 2005:80-95.
11. Septia A, Rahmalia S, Sabrian F. Relationship With Family Support Compliance Drink Drugs In Patients with Pulmonary Tb There is a relationship with the family support medication adherence in patients with pulmonary tuberculosis at the Regional General Hospital Arifin Achmad. JOM PSIK. 2014;1(2).

12. Erawatyningsih P, Heru Subekti E. Faktor-Faktor yang Mempengaruhi Ketidakpatuhan Berobat pada Penderita Tuberkulosis Paru. Jurnal Berita Kedokteran Masyarakat (BKM). 2012;25(3):117.

13. Karyadi E, West C, Nelwan R, Dolmans W, Schultink J, Van Der Meer J. Social aspects of patients with pulmonary tuberculosis in Indonesia. 2002.

14. Rangan S, Uplekar M, Porter J, Grange J. Socio-cultural dimensions in tuberculosis control. Tuberculosis: an interdisciplinary perspective. 1999.

Cite this article as: Mongan $\mathrm{R}$, Fajar. Relationship between Family Support and Medical Compliance in Patients with Pulmonary Tuberculosis in the Working Area of the Community Health Center of Abeli, Kendari. Public Health of Indonesia 2017; 3(1):17-22. 